Table Prevalence of infection with various pathogenic agents in parturients, antenatal clinic attendants and STD clinic attendants in Cameroon (1990)

\begin{tabular}{|c|c|c|c|}
\hline & Parturients & $\begin{array}{l}\text { ANC } \\
\text { attenders }\end{array}$ & $\begin{array}{l}S T D \text { clinic } \\
\text { attenders }\end{array}$ \\
\hline $\begin{array}{l}\text { C. trachomatis } \\
\text { No tested } \\
\text { No positive } \\
\% \text { positive } \\
95 \% \text { CL }\end{array}$ & $\begin{array}{l}69 \\
30 \\
43 \cdot 3 \% \\
31 \cdot 6-55\end{array}$ & $\begin{array}{l}\text { ND } \\
\text { ND } \\
\text { ND } \\
\text { ND }\end{array}$ & $\begin{array}{l}135 \\
24 \\
17 \cdot 8 \% \\
11 \cdot 3-24 \cdot 3\end{array}$ \\
\hline $\begin{array}{l}N \text {. gonorrhoea } \\
\text { No tested } \\
\text { No positive } \\
\% \text { positive } \\
95 \% \text { CL }\end{array}$ & $\begin{array}{l}69 \\
23 \\
33 \cdot 3 \% \\
22 \cdot 2-44 \cdot 4\end{array}$ & $\begin{array}{l}\text { ND } \\
\text { ND } \\
\text { ND } \\
\text { ND }\end{array}$ & $\begin{array}{l}120 \\
16 \\
13 \cdot 3 \% \\
7 \cdot 2-19 \cdot 4\end{array}$ \\
\hline $\begin{array}{c}\text { Reactive TPHA } \\
\text { No tested } \\
\text { No positive } \\
\% \text { positive } \\
95 \% \mathrm{CL}\end{array}$ & $\begin{array}{l}\text { ND } \\
\text { ND } \\
\text { ND } \\
\text { ND }\end{array}$ & $\begin{array}{l}350 \\
61 \\
17 \cdot 4 \\
13 \cdot 4-21 \cdot 4\end{array}$ & $\begin{array}{l}192 \\
41 \\
21 \cdot 4 \% \\
15 \cdot 6-27 \cdot 2\end{array}$ \\
\hline $\begin{array}{l}H I V-1 \\
\text { No tested } \\
\text { No positive } \\
\% \text { positive } \\
95 \% \mathrm{CL}\end{array}$ & $\begin{array}{l}\text { ND } \\
\text { ND } \\
\text { ND } \\
\text { ND }\end{array}$ & $\begin{array}{l}\text { ND } \\
\text { ND } \\
\text { ND } \\
\text { ND }\end{array}$ & $\begin{array}{l}93 \\
6 \\
6 \cdot 5 \% \\
1 \cdot 5-11.5\end{array}$ \\
\hline
\end{tabular}

$\mathrm{CL}=$ confidence limits, $\mathrm{ND}=$ not done.

chlamydial antigens was $15.9 \%$ in men $(11 / 69)$ and $19.7 \%$ in women $(13 / 66)$, while that for Neisseria gonorrhoea antigens was $16.7 \%$ in men $(9 / 54)$ and $10 \cdot 7 \%$ in women (7/66). Infection with both agents was present in nineteen parturients $(27.5 \%)$ and two of 120 STD clinic attendants tested $(1 \cdot 7 \%)$

Sex prevalence for TPHA reactivity among STD patients, was $19 \cdot 8 \%$ for men $(18 / 91)$ and $22 \cdot 8 \%$ for women $(23 / 101)$.

Of the 93 subjects who consented to HIV testing, six were positive for HIV-1 $(6 \cdot 5 \%)$ and none for HIV-2. Among the positives were five of 46 men $(10.9 \%)$ and one of 47 women $(2 \cdot 1 \%)$. None of these $6 \mathrm{HIV}$-positive subjects tested positive on either chlamydiazyme or gonozyme. However, three of them $(50 \%)$ were TPHA reactive.

Our study confirms that Chlamydia trachomatis is common in certain populations in Cameroon and that for both chlamydia and gonorrhoea, the prevalence in our parturients was very high. This may reflect the asymptomatic nature of these infections in women Those we tested also belong to the lowest socioeconomic classes. Self medication in the STD clinic attenders may explain why their prevalences are lower than those found in the parturients.

TPHA reactivity was slightly lower in antenatal clinic attendants $(17 \cdot 4 \%)$ than in the STD clinic attendants $(21.4 \%)$ but the difference was not significant $(p>0.05)$.

The prevalence of HIV infection in the STD clinic attendants was $6.5 \%$; with a strong suggestion of an association between a positive TPHA reactivity and a positive HIV status, as reported by Zekeng et al. ${ }^{5}$

The potential effects of these infections such as infertility, ectopic pregnancy, infant blindness, mental retardation, and the fact that these are preventable, imposes an urgency for intervention. ${ }^{1-4}$
An STD/HIV control programme is being developed with the collaboration of women's groups, STD clinics and primary health care centres.

We thank Dr A Andela, head of the Central Antenatal clinic in Yaounde for his cooperation. The Virus Immunology Unit is supported in part by the University of Yaounde and the AIDS Task Force of the EEC.

$$
\begin{array}{r}
\text { P M NDUMBE } \\
\text { E WATONSI } \\
\text { P NYAMBI } \\
\text { Virus Immunology Unit, Department of Pathological Sciences, } \\
\text { Centre Universitaire des Sciences de la Sante, CUSS, } \\
\text { University of Yaounde } \\
\text { P MBAYA } \\
\text { The Central Maternity, Laquintinie Hospital, Douala } \\
\text { D YANGA } \\
\text { The Centre, Medico-Social, Yaounde, Cameroon }
\end{array}
$$

Address for correspondence: Dr P M Ndumbe, Virus Immun Unit, Centre Universitaire des Sciences de la Sante (CUSS), Yacunde, Cameroon.

Piot P, Holmes KK. Sexually transmitted diseases. In: Warren KS, Mahmound AAF (eds). Tropical and Geographical Medicine. New York: McGraw-Hill, 1984: 844-862.

2 Pepin J, Plummer FA, Brunham RC, Piot P, Cameron DW, Ronald AR. The interaction of HIV infection and othe sexually transmitted diseases: an opportunity for intervention. $A I D S 1989 ; 3 ; 3-9$.

3 Plummer FA, Simonsen JN, Cameron DW, Ndinya-Achola JO, Kreiss JK, Gakinya MN, Waiyaki P, Cheang M, Pio P, Ronald AR, Ngugi EN. Cofactors in male-female transmission of human immunodeficiency virus type 1 . Infect Dis 1991;163:233-9.

4 Wesserheit JN. The significance and scope of reproductive tract infections among third world women. Int $J$ Gynecol Obstet 1989;Suppl. 3:145-168.

5 Zekeng L, Yanga D, Sokal D, Salla R, Kaptue L. HIV infection among STD patients in Yaounde, Cameroon. VIIth International Conference on AIDS, Florence, Italy, June 16-21, 1991.

Accepted for publication 2 January 1992

\section{Carriage of Chlamydia trachomatis by} elderly people

To determine the detection rate of Chlamydia trachomatis in culture negative urine samples, non invasive methods have been successfully applied in the past. ${ }^{12}$ We employed the amplified ELISA technique ("IDEIA", Boots Celltech) to detect Chlamydia trachomatis in urine samples which showed 50 pus cells $/ \mu$ l on microscopy but had no growth or contaminants only on culture.

Urine specimens $(\mathrm{N}=249)$ meeting our criteria irrespective of age and sex of the patients were examined by this method on the centrifuged deposit. There were 10 positive samples $(4.0 \%)$, of which three were from male and seven from female patients. Two patients were, however, over the age of 65 years.

The purpose of this communication is to draw attention to some interesting questions raised by this small scale study like:

(1) Do we know the true incidence of chlamydia in the elderly population? It is important to bear in mind in this context that contrary to 
traditional belief not an insignificant number of elderly people are engaged in sexual activity as has been described recently. ${ }^{3-5}$

(2) What are the long term sequelae of carriage of chlamydia without treatment.

(3) What is frequency of false positive ELISA tests amongst low risk patients as in this study in the absence of facilities for simultaneous culture for chlamydia. B CHATTOPADHYAY
Public Health Laboratory and Department of Microbiology, Whipps Cross Hospital, London E11 INR, UK

1 Caul EO, Paul ID, Milne JD, Crowley T. Non-invasive sampling method for detecting Chlamydia trachomatis. sampling method for

2 Matthews RS, Bonigal SD, Wise R. Sterile pyuria and Chlamydia trachomatis. Lancet 1990;336:385

3 Kellett JM. Sex and the elderly. BMJ 1989;299:934.

4 Lawton FG, Hacker NF. Sex and the elderly. $B M$ 1989;299:1279.

5 Rogstad KE, Bignell CJ. Sex and the elderly. 1989;299:1279.

\section{Annular lesions in congenital syphilis}

The incidence of congenital syphilis has markedly decreased over the years. However, in underdeveloped societies where proper antenatal care clinics are still not established, sporadic cases of congenital syphilis are seen. Recently we have seen a case of congenital syphilis which presented with well defined annular lesions mimicking tenia infection.

A one year old female child, born after 8 months of gestation, presented with a progeric look and

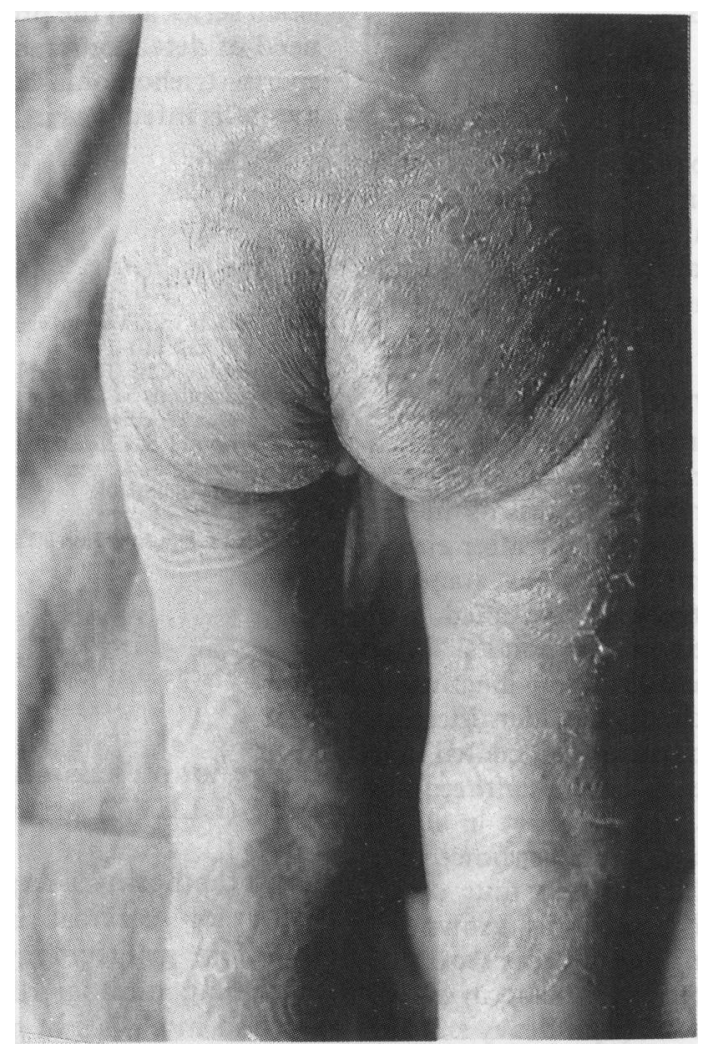

Figure 1 Well defined scaly lesions with raised borders over buttocks and popliteal fossa.

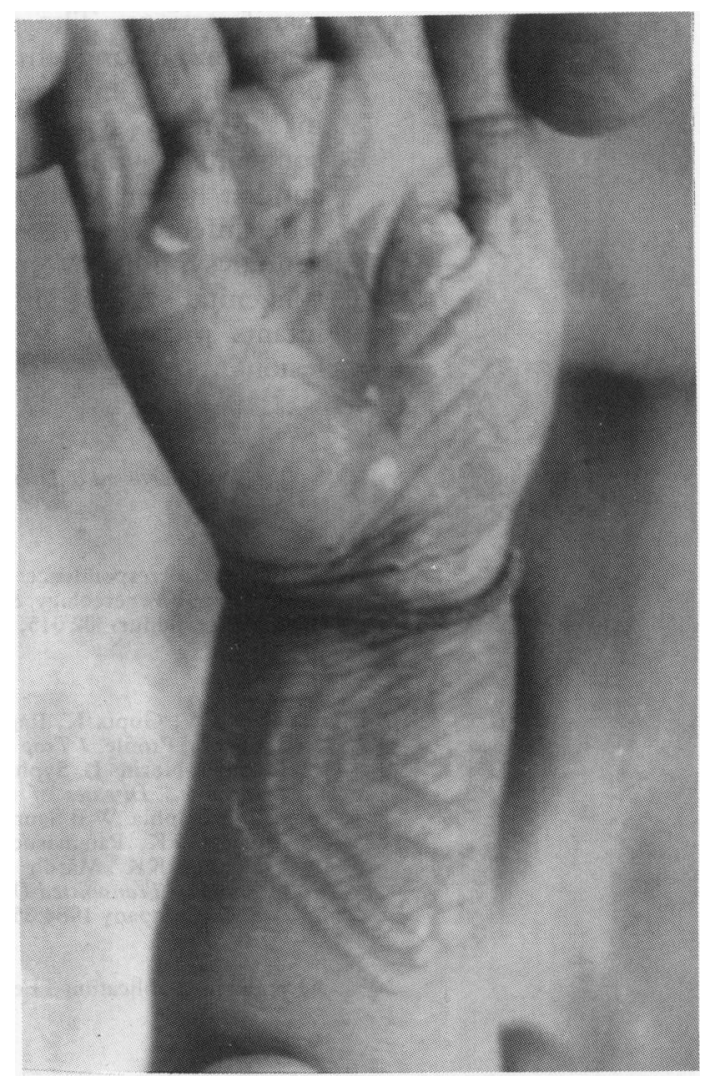

Figure 2 Successive rings over wrist with scaling of palm.

multiple wide spread, asymptomatic skin lesions. The lesions were more or less symmetrical, well defined, hyperpigmented, scaly and annular with central clearing. Patches over the wrists showed successive rings mimicking ternia imbricata (figs 1 $\& 2)$. The child also had recurrent serosanguinous discharge from the nose, frequent episodes of upper respiratory tract infection and diarrhoea.

Examination of the child revealed delayed milestones, unclosed anterior fontanalle, sparse and lustreless hair, depressed nose, absence of nasal septum, stenosed nasal cavity and generalised lymphadenopathy. The skin of the palms and soles had only fine scaling. Mucous membranes, eyes, liver and spleen were normal. Serum VDRL was positive in both mother (1:32) and child $(1: 1024)$ while negative in the father. Similarly FTA-abs test was positive in the mother and child and negative in father. The parents as well as child were negative for HIV antibodies. Skeleton radiographs showed periosteal reaction in the upper end of the tibiae with deposition of new bone under the periostium, ostiochondritic changes in the upper end of tibiae, fibulae and lower end of the femurs. Potassium hydroxide mount and culture for fungus were negative. Her skin lesions cleared soon after penicillin therapy which further confirmed that the annular skin lesions were manifestion of syphilis.

The common clinical presentation of congenital syphilis include skin lesions, osseous changes, hepatosplenomegaly and anaemia. ${ }^{1}$ The incidence of mucocutaneous lesions in congenital syphilis varies from $15-60 \%{ }^{2}$. Vesiculobullous eruptions, papular or papulosquamous lesions, wrinkling of skin, moist lesions like condyloma lata and desquamation of skin are the usual cutaneous 